\title{
Gravity model analysis of globalization process in transition economies
}

\author{
Andriy Stavytskyy \\ Department of economic cybernetics, \\ Taras Shevchenko National University of Kyiv, \\ Ukraine \\ a.stavytskyy@gmail.com
}

\section{Ganna Kharlamova}

Department of economic cybernetics,

Taras Shevchenko National University of Kyiv,

Ukraine

akharlamova@ukr.net

\author{
Vincentas Giedraitis \\ Vilnius University, \\ Lithuania \\ vincas.giedraitis@ef.vu.lt \\ Ezgi Ceylan Sengul \\ Vilnius University, \\ Lithuania \\ ezgics@gmail.com
}

Abstract. The globalization process develops itself differently for each transition country. Likewise, implementation of reforms and their impacts on trade relations show variety among countries. The article focuses on five countries (Finland, Estonia, Latvia, Lithuania, and Ukraine). It considers how the factors (the size of the economy, the ratio of the price index of the countries, common borders on the sea or on land, distance between the states and the existence of common currency) have affected the export trade volume with trading partners during 1996-2017. The main methodology of the article is formed around the gravity model, which suggests that trade relations between countries can be explained by their economic size and the distance between states' financial centres. The findings show that such factors still play a significant role, but logistic problems became much weaker during the last years. It is necessary to note the influence of the Industry 4.0, which intensifies the service of the economy and introduces new adjustments to the allegedly established

Received: December, 2018 1st Revision: February, 2019 Accepted: April, 2019

DOI:

10.14254/2071$8330.2019 / 12-2 / 21$ 
theoretical dependencies in trade and economic development of the state. The research has shown that countries that are close to each other have fewer opportunities for developing export potential. At the same time, the presence of a common currency allows states increase exports by about one-fifth. At present, changes in domestic prices in countries do not play a significant role in exports, same as the ratio of the economy size. Therefore, taking into account the development of transport infrastructure, it is possible to increase significantly the exports in Europe, especially with the involvement of Eastern Europe.

Keywords: globalization, gravity model, trade, exports, transition, Baltic states, Ukraine.

JEL Classification: P33, F1, C01

\section{INTRODUCTION}

The breakdown of the Berlin Wall and the collapse of the Soviet Union in the following years led centrally-planned economies ruled by communism to transform themselves to free-market economies. A number of countries gained their independence through economic and political revolution. The transition process has been managed by each transition country in its own way. Liberalization of prices, capital flows, elimination of trade barriers and technological developments accelerated the process and the impacts of globalization (Dudzevičiūtè, 2012).

As a result of the globalization processes, openness of the country borders for the movement of goods, services, capital and labour, the interdependence of states is only intensifying. This means that virtually no country can choose its economic policy without taking into account international trends, without analyzing the possible impact of global processes on its economy. The problem of choosing the optimal policy is complicated by the fact that, due to the development of competition, all solutions need to be taken as quickly as possible, as the rapid impact of changes in other countries can cause significant damage to the economy and its export/import capacities. The experience of the financial crisis of 2008 and also military conflicts of the recent years suggests that ignoring challenges, threats along with untimely decision-making lead to the destruction of the economy, further stratification of the society, escalation of social problems. Despite broad discussions of the world trade of the development and integration of the transition economies, there still an obvious lack of research modelling synergy and neighbourhood impacts in this regard. Thus, the ambition of this paper is to apply the gravity approach to demonstrate this "domino effect" on a model. This would contribute novelty to the research field in comparison with the previous studies discussed below in the literature review part of this paper.

Thus, the aim of this article is to provide an assessment of the transition process in the analysed states by investigating their export volumes. We expect to receive answers to the following several questions:

- What factors determine the export potential of countries?

- Have the perceptions of merchantability that have been established in the last century changed?

- Are there any new factors determining the export potential of the country?

-What is the role of logistic problems in exporting?

-Why do neighbouring countries trade at a slower pace than those located farther from each other? 
- What is the divergence between country's economic development and the volume of its exports, as gravity relations can arise in almost any trade model that includes trade costs that increase with the distance?

In order to fulfil the analysis, the gravity model is used to determine trade patterns (exports in goods and services) of Finland, Estonia, Latvia, Lithuania and Ukraine.

\section{LITERATURE REVIEW}

Globalization has been as an arguable phenomenon throughout history. Especially economic, social and political interpretations of globalization help to explain the transforming effect of it on the world system as well as on the transition countries. Particularly, the collapse of real socialism, thus the spread of liberal economic system or free market economy caused each of developing and developed countries to become alike by using similar economic policies based on delimitating state interventions (Lankauskienè \& Tvaronavičienè, 2012; Pietrasieński \& Ślusarczyk, 2015).

According to OECD indicators, the influence of globalization showed itself by the effectiveness of capital movements and foreign direct investments, international trade, the internationalization of technology and the economic activities of international companies (OECD, 2005).

The transition countries, particularly the Baltic States, had a common legacy from the Soviet Union and the initial conditions of reforms, nonetheless, the implementation process and transition strategies were different for each of them. The potential of countries showed the importance for them to choose strategies to follow. The potential includes the development level of a country, reforms, integration level to Soviet past, domestic and international macroeconomic balance, raw material resources and distribution to the foreign markets, political situation and liberal movements within the country (Gelb, et al 1999). Based on the mentioned, the Baltic States' strategy was to choose shock therapy in order to implement reforms and complete transition rapidly (Tešić, 2012).Still, as all countries in transition: Estonia, Latvia and Lithuania, have gone through the process of privatization and restructuring, macroeconomic stabilization, liberalization and institutional and legal reforms (Zenonas, 2007). According to Korhonen, economic reforms in these states have been performed faster and more comprehensive than other Former Soviet Union countries. Despite the fact that at the beginning of transformation process all countries had common economic problems especially with the decrease in output, the Baltic States seemed to be relatively similar to each other in terms of the building new economic structures (Korhonen, 2001).

There is a completely different situation in another post-Soviet country - Ukraine. Due to the lack of reforms, the high corruption component, the lack of coordination of the development strategy, significant economic and political dependence on the Russian Federation, Ukraine has failed to take the steps necessary to implement a real market mechanism. The situation changed a little bit in 2014 after the Revolution of Dignity and the beginning of the war with Russia. However, the allocation of significant funds for strengthening the defence capacity inhibits the path of development.

At the same time, current trends show that geopolitical and geo-economic factors play a leading role in shaping both economic policy and the country's development. Recent trends indicate that the role of commodity economies should be significantly reduced. In particular, Stavytskyy researched that for the last decades the prices for the main resources have increased by 2-5 times slower than the prices of technological companies stocks (Stavytskyy, 2018a, b). This means that new technologies should be the basis for further development, which, first of all, will reduce the dependence of economies on energy. This can be achieved by increasing renewable energy sources (Stavytskyy, et al., 2018; Ślusarczyk et al., 2016). These days about $20 \%$ of electricity is produced from renewable sources in some countries. According to current trends, almost all electricity will be produced using alternative energy by 2050 . 
Apparently, this process enhances the energy security of Europe and the world, as well as contribute to the better support of human needs. Of course, this could cause certain threats to economic growth. In particular, cheaper energy leads to an increase in output, which creates preconditions for further mechanization of production, and hence the replacement of people by robots. On the one hand, this trend leads to an increase in income inequality, but, on the other hand, the state has powerful tools to address these problems through fiscal mechanisms (Kharlamova, et al, 2018). The development of technologies can significantly reduce the cost of transporting products, the speed of delivery of goods, and therefore the obstacles that hinder the development of trade and economic globalization, are gradually decreasing. This leads to a significant increase in exports of goods and services. In fig. 1 shows the dynamics of exports of goods and services in billions of dollars at constant prices in 2010 for all countries and countries in Europe and Central Asia. As can be seen, overall exports over the past 37 years have grown by 5.72 times in constant prices, corresponding to average annual growth of $4.82 \%$. For European and Central Asian countries, exports increased by 4.79 times or $4.32 \%$ per year.

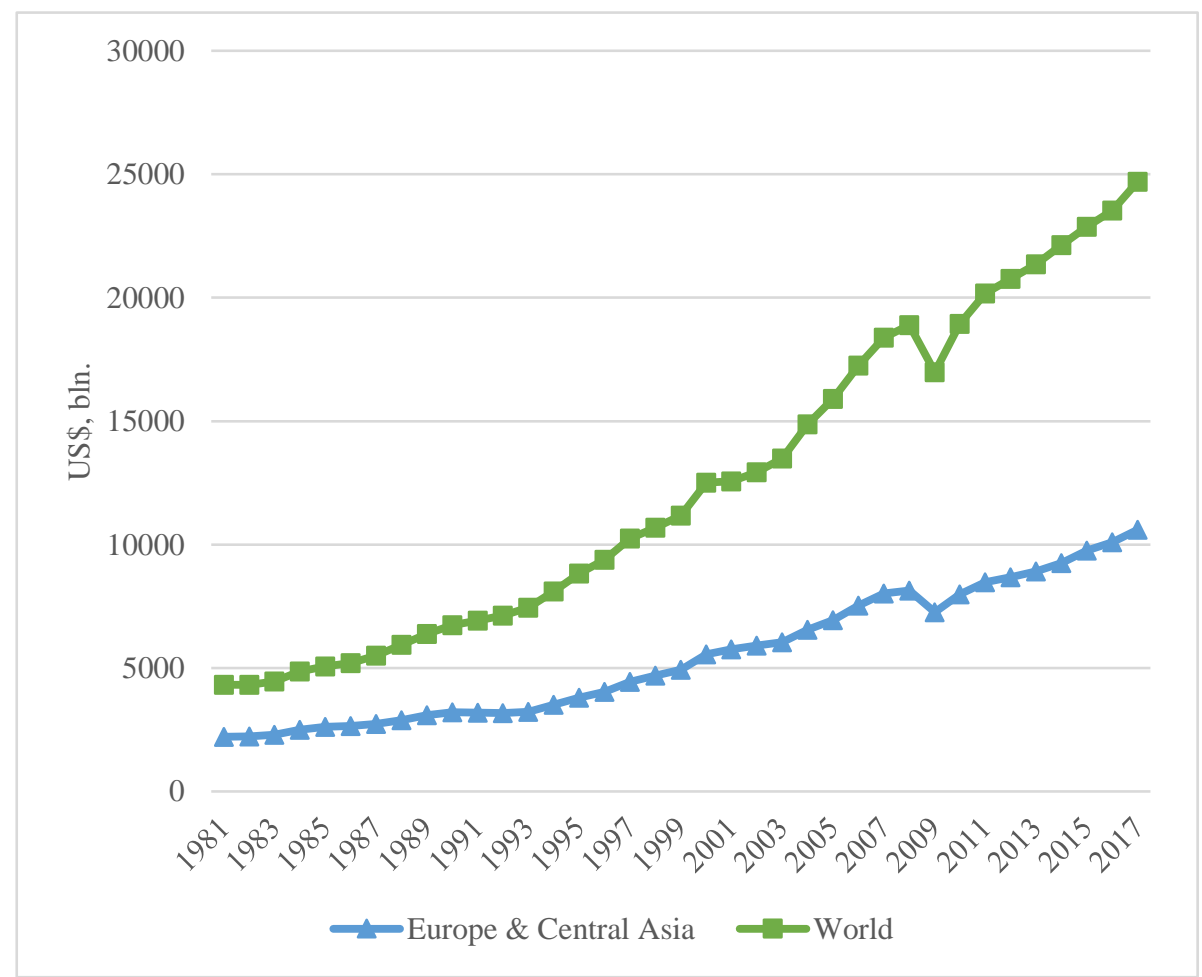

Figure 1. Dynamics of exports of goods and services at constant prices in 2010

Source: authors' calculations based on the data of the World Bank

(https://data.worldbank.org/indicator/NE.EXP.GNFS.KD?end=2017\&start=1960\&view=chart)

Generally, the research of triad: globalization - economic development - trade, have found its progress in the assessment of the external trade convergence to determine the convergence efficiency in the foreign trade between rich and poor countries (Ben-David, Loewy, 1998). Given the EU's volume of international trade and its extensive involvement in bilateral and multilateral trade arrangements, a better understanding of how the EU makes external trade policy is increasingly important (Reichert \& Jungblut, 2007). As a rule, countries show more rapid convergence of exports compared to the convergence of imports level. Still, some researches prove that trade-related convergence is still in place, and it confirms the presence of an overtaking effect between poor and rich EU countries. For the last 14 years, the difference between the poor and rich EU countries is decreasing over time due to carrying out of export 
and import operations. Nevertheless, estimating the convergence rate and time to overcome half of the distance in the converging levels for countries, scientists concluded that convergent links between EU countries are extremely weak (Barro, Sala-i-Martin, 1990; Sala-I-Martin, 1996; Vamvakidis, 2008). There is quite broad research based on demonstrating the differences in the intensity of use of production factors in the exports of the European Union states, whichcannot be explained only by resources at the disposal of these countries. These authors provide empirical evidence that the resources of production factors have no direct impact on the export structure and the chosen direction of economic cooperation is essential (Basile, 2017; Bittmannova, 2016).

Very demonstrative are recent researches that consider the damage of the current game rules in the international trade - like Brexit (Oberhofer \& Pfaffermayr, 2018) or US Withdrawal from International Trade (Robinson \& Thierfelder, 2018) - by means of gravity approach for estimating the trade and welfare effects. Thus, assuming different counterfactual post-Brexit scenarios, authors suggested that UKs (EU) exports of goods to the EU (UK) are likely to decline within a range between $7.2 \%$ and $45.7 \%(5.9 \%$ and $38.2 \%$ ) six years after the Brexit has taken place. For the UK, the negative trade effects were only partially offset by an increase in domestic goods trade and trade with third countries, inducing a decline in UK real income between 1.4\% and 5.7\% under the hard Brexit scenario. The estimated welfare effects for the EU were negligible in magnitude and statistically not different from zero (Oberhofer \& Pfaffermayr, 2018). In its turn, exploring the implications of a NAFTA collapse and the potential disintegration of the North American trade bloc indicated modest macroimpacts on the US and much larger impacts on Canada and Mexico. Authors received evidence of the possible significant sectoral impacts in all three countries, especially for agriculture and motor vehicle (Robinson \& Thierfelder, 2018).

\section{METHODOLOGY}

For our study, the following hypotheses were formulated.

Hypothesis 1. The volume of GDP of the country positively affects the volume of exports.

Obviously, the volume of exports is significantly related to the volume of GDP (Makštutis, et al, 2012). Albeit, this dependence can hardly be considered straightforward. Exports are the basis of GDP for poor or resource-dependent countries. If the state manages to maintain at least a constant share of exports in GDP, then under such conditions the volume of GDP will increase. Conversely, the growth of the main economic indicator will stimulate the development of the domestic market, which, in turn, will contribute to the fall in the share of exports in GDP. If a country becomes more prosperous, exports and imports are levelled out, the share of exports does not play a significant role. Thus, this hypothesis will allow us to verify the stage of development for the studied countries.

Hypothesis 2. The volume of GDP of a partner country positively influences its import volume.

On the one hand, the GDP growth of the partner country contributes to higher volumes of acquisitions (Harms \& Méon, 2018). On the other hand, the more prosperous is the country, the more demanded it is to the quality of products, delivery conditions, etc. Since these effects are reversed, it is necessary to determine which one is predominant for the countries under our study.

Hypothesis 3. The GDP ratio of trading partners in the modern world does not play a significant role in the analysis of exports.

According to Krugman's new theory, trade is first and prime between comparable economies (Krugman, 1998). It is necessary to investigate whether this thesis is confirmed in the conditions of world globalization and simplification of trade conditions.

Hypothesis 4. The CPI ratio in partner countries contributes to the growth of exports. 
According to economic theory, the difference between domestic and foreign products' prices is an incentive for imports (Costinot \& Rodríguez-Clare, 2018). However, countries may sometimes restrict imports through protectionist measures. The hypothesis checks whether the restriction of access to markets is successful in the current conditions.

Hypothesis 5. The presence of common borders contributes to the growth of exports.

Economic theory shows that neighbouring countries have all the incentives to start trading (Rodrik, 2018). Obviously, countries will be interested in such a trade. But, in most cases, neighbours have a similar range of products, which limits the opportunities for increased trade. As a result, it is necessary to investigate the impact of the existence of common borders in the modern world. In testing the hypothesis we will proceed from the fact that common borders can be on land. At the same time, if several countries are located quite close to each other, and only a small part of the sea shares them, then in certain cases these states can be considered as neighbours. In our study, we will check both options.

Hypothesis 6. A significant distance for the transportation of goods is an obstacle to the growth of exports.

The distance is the basis for constructing a gravity model (Eaton \& Kortum, 2018). The bigger the distance, the higher the costs are paid by the product manufacturers for its delivery, which should reduce the volume of exports. It is necessary to check the execution of this statement and estimate the real cost of logistics in trade.

Hypothesis 7. The introduction of the euro has a positive effect on the volume of exports.

Since 1999, European countries are trying to enter a common currency. According to economic assumptions, the absence of currency risks and the need for bureaucratic formalities to purchase the currency, positively contribute to the development of trade. As most of the transition countries are not yet ready to launch the common currency, it is worthwhile estimating what share of exports they are potentially losing (Ocampo, 2018).

Hypothesis 8 . The presence of the euro in circulation in the partner country stimulates exports.

In this hypothesis, it is assumed that the possibility of obtaining a fairly stable currency (euro) for its commodity encourages manufacturers to sell goods to such countries (Cohen, 2018).

Thus, in the study, we will examine the eight hypotheses presented.

Data. The study analyses Finland, Estonia, Latvia, Lithuania and Ukraine. The choice of countries is explained by the following factors. First, these countries are relatively close to each other, and the size of their economies is comparable as a whole. Secondly, they relate to different developmental groups. In particular, Finland is a developed country that initially took an active part in the European Union, introduced the euro in the first group of countries in 1999. Estonia is the most developed from the Baltic countries, which has moved to the Eurozone since 2011. Latvia and Lithuania introduced the euro in 2014 and 2015, respectively. All these countries are already fully integrated into the European Union, but over the period from 1992 to 2017, they have undergone a difficult transformation path. Ukraine is on its way now, which has set the goal of joining the European Union. Therefore, these countries are actually divided into three groups: well-developed, newly developed, and on the way of the transformation. To test hypotheses, the following database was compiled containing annual data for these five countries:

Exp_index - the variable that defines the export index to the partner country, 1 is the level of 2015. For the analysis, the export index was taken instead of the nominal values due to the need to avoid nonstationary processes for further calculations. In 2016, exports of services and goods accounted for 58\%, $80 \%$ and $74 \%$ of GDP in Latvia, Estonia and Lithuania respectively (Fig. 2). It means that Latvia historically falls behind both neighbouring countries, and its recent growth has not helped Latvia to catch up with Lithuania and Estonia. In 2016, the large difference between Latvia and Lithuania was mainly due to re-exports. The market share of Latvia's exports of goods in global imports is expanding at a faster rate 
than that of the other Baltic States suggesting an improvement in Latvia's competitiveness. However, the volume and the value of goods exported from Latvia are still lower compared to exports from Estonia and Lithuania. In 2017 Finland exported $\$ 70.7 \mathrm{~B}$, making it the 40th largest exporter in the world. During the last five years the exports of Finland have decreased at an annualized rate of $-1.5 \%$, from $\$ 75.7 \mathrm{~B}$ in 2012 to $\$ 70.7 \mathrm{~B}$ in 2017. Exports in Ukraine decreased to 3893.30 USD Million in February 2019 from 4062 USD Million in January of 2019. Exports in Ukraine averaged 3713.86 USD Million from 2001 until 2019, reaching an all time high of 7616.80 USD Million in July of 2008 and a record low of 1215.20 USD Million in January of 2002.

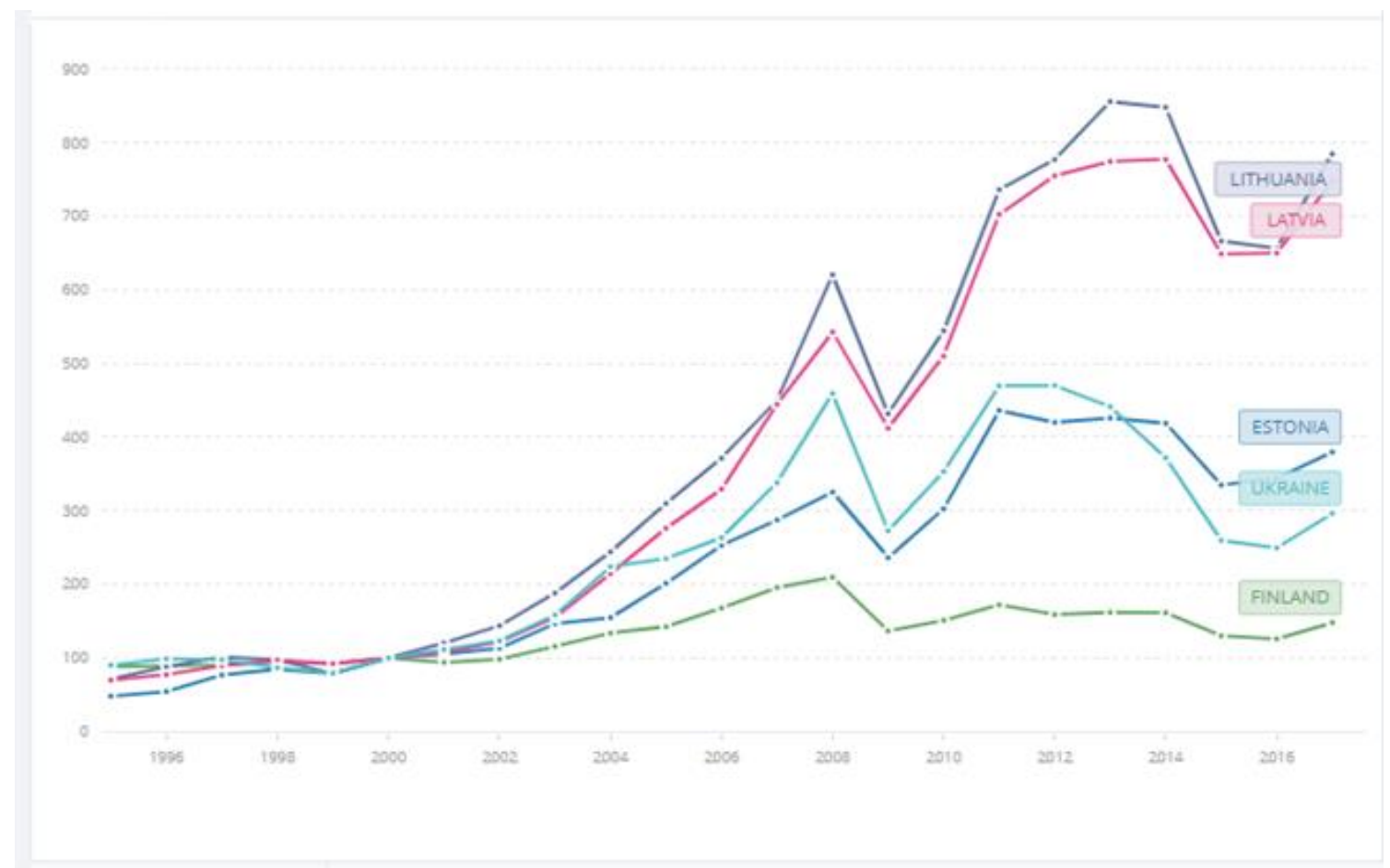

Figure 2. Export value index in selected countries $(2000=100)$

Source: authors' calculations based on the data of the World Bank

Having a glance at the graph, we see like three levels of co-dynamics: for Finland - the lowest level, for Ukraine and Estonia - the middle and the highest - for Lithuania and Latvia.

GDP_ratio - the ratio of the GDP of the exporting country to the GDP of the importing country. This change characterizes the extent to which the economy of one country prevails over the other.

GDP_index_C1 - the index of GDP of the exporting country, the level of 2015 equals to 1. Similarly, to the export index, it was necessary to replace the data with nominal values to avoid non-stationary processes.

GDP_index_C2 - GDP index of the importing country, 2015 level is 1.

Generally, we see that the dynamics of GDP indicator (Fig. 3) is the similar to crisis periods. As to Ukraine, we observe the convergence of Ukrainian indicator to the EU analysed state since 2000 but the lost of this synergy in 2015, that could be explained by the war situation at the East of the country.

CPI_ratio - the ratio of the price index of the countries, the level of 2015 in all countries equals to 1. This indicator shows the current CPI ratio in partner countries. As we see from the graph, Ukraine has an absolutely dramatic trend in comparison to the rest analysed states. Meanwhile, all states under analyses demonstrate growing tendency in CPI since 1991. 


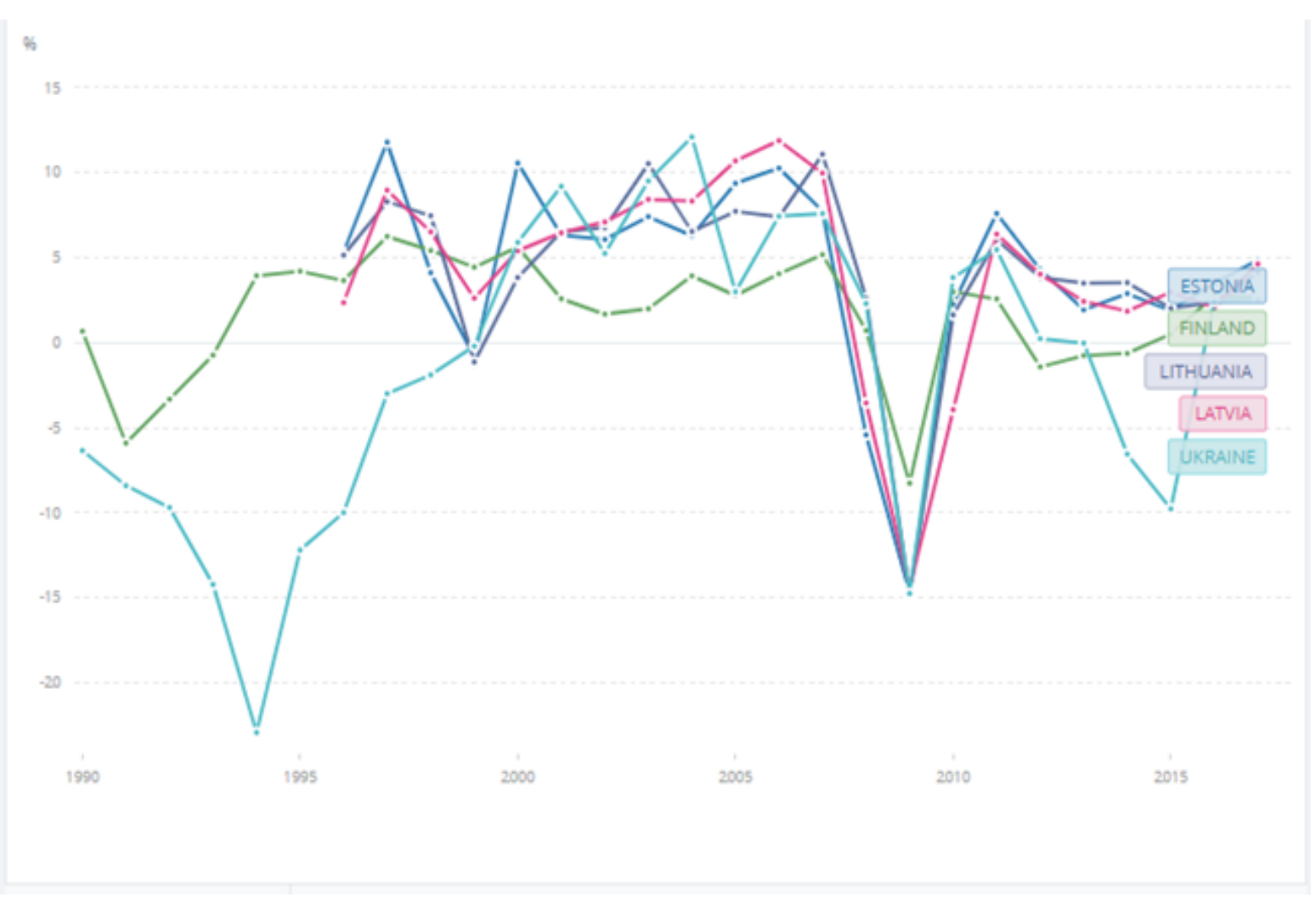

Figure 3. GDP growth in selected countries (annual \%)

Source: authors' calculations based on the data of the World Bank

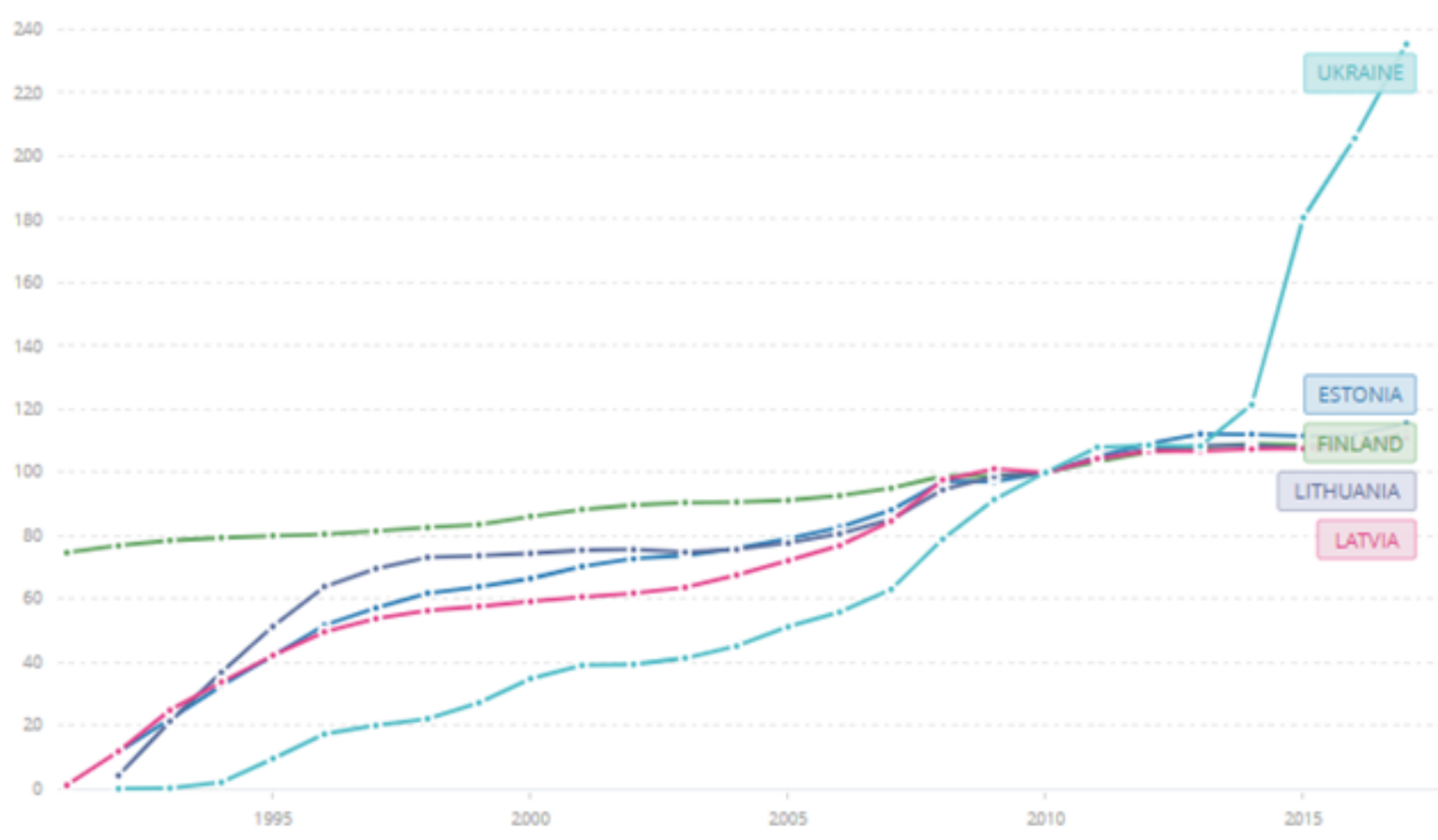

Figure 4. Consumer price index in selected countries $(2010=100)$

Source: authors' calculations based on the data of the World Bank 
Dist - the distance between the capitals of the states in $\mathrm{km}$. The distance was measured using Google Maps using standard automobile roads. It should be noted that the distance analysed between the capitals, although the delivery of goods does not always happen exactly between them. It is also interesting that the distance between the two cities in different directions may be insignificantly unequal (see the table in Annex).

ComBorder - the existence of a common land border between countries. If there is such a border, then the variable takes value 1 , otherwise, it is 0 .

SeaBorder - the presence of ports in the common sea. If there is such a port, the variable takes the value 1, otherwise, it is 0. For example, Finland and Estonia do not have a common border, so the ComBorder variable is 0 , but both countries have ports in the Baltic Sea, so SeaBorder equals to 1.

Eurozone - this variable takes value 1 if both countries use the euro as the monetary unit, 0 otherwise

Im_euro - this variable equals1 if the importing country uses the euro as a monetary unit, 0 otherwise

The database was created using data from the World Bank, Eurostat, and the State Statistics Service of Ukraine. Time duration should include the period since the Baltic States have gained their independence back. Despite the fact that all Baltic countries were independent by the end of 1991, remarkable trade activities of exporters started after 1994. Due to the reconciliation of data, (there is no part of the information for 1995 for Ukraine), the entire database starts in 1996.

The principle of database construction allowed getting the stationary processes for the model at once. In table 1 the results of joint testing of all variables (except dummy ones) for common stationarity with the help of the criterion of Breitungt-statistics Common Root test are given.

Table 1

Verification of data for stationary

\begin{tabular}{|c|c|c|}
\hline Method & Statistic & Prob. \\
\hline EXP_INDEX & -3.95463 & 0.0000 \\
\hline GDP_INDEX_C1 & -3.63715 & 0.0001 \\
\hline GDP_INDEX_C2 & -3.63715 & 0.0001 \\
\hline GDP_RATIO & -1.75562 & 0.0396 \\
\hline DIST & -4.04809 & 0.0000 \\
\hline CPI_RATIO & -5.24603 & 0.0000 \\
\hline
\end{tabular}

Source: calculated by authors

The Gravity Model. The gravity model equation is used to accomplish the study. The starting point of the gravity theory in economics based on Newton's law of gravitation (Anderson, 1978). The simple gravity model was outlined by Tinbergen in 1962 based on trade level between countries as a dependent variable and the economic size of their trading partners and the distance between countries' financial centres as independent variables. There are a lot of attempts to apply gravity models to arrange ideas in the economic theory. Still, despite the gravity equations' empirical successes in "explaining" trade flows, the model's predictive potential has been inhibited by an absence of strong theoretical foundations (Bergstrand, 1985; Binh, et al, 2011; Christie, 2002). For the Baltic states and Ukraine, there are some publications on the base of gravity models like Byers, et al, 2000; Ravishankar, Stack,2014. The opening up process of the eastern European countries is characterised by an increasing degree of trade integration with their Western neighbouring countries (Ravishankar \& Stack, 2014; Kepaptsoglou, et al. 2010). The authors attempted to provide evidence on the effects of an economic and political union by studying the 
trade flows of the three Baltic countries of Estonia, Latvia and Lithuania after the breakup of the Soviet Union. They resulted that Baltic foreign trade was not only reduced significantly but also diverted to the members of the former Soviet Union. Still, these consequences of the former political union are quickly dissipating, and the Baltic countries are increasing their share of exports to the European Union and the U.S (Byers, et al, 2000).

The econometric tools of gravity modelling in recent decades have been significantly enriched due to the emergence of theoretically grounded modifications of gravity equation: calculation of remoteness indicators, use of price indices, non-linear estimation of Anderson and van Vinkoop, linear approximation of Bayer and Bergstrand's rationing, the fixed effects of the exporter and importer. The options for panel gravity specifications are discussed: fixed or random effects for pairs of countries, the Houseman-Taylor model (Westerlund \& Wilhelmsson, 2009; Santos Silva \& Tenreyro, 2006).

The gravity model has the advantage of having greater credibility over ad hoc 'reduced form' regression models by explaining how these variables interact. Regression models that just throw covariates on the right hand side and run OLS approximate the dependent variable with a linear combination of the covariates. However, there is no reason why a linear combination is superior to a linear combination of the logs of the variables, or the squares, or the n-th powers. The theory used to justify the gravity model removes this ambiguity in specifications by imposing a particular functional form (Ramos, 2016). As advantages of the gravity model Ramos (2016) and other (Karemera et al, 1999; Egger, 2002) indicate:

- it provides an intuitive framework to understand the determinants of flows between countries, in particular, trade, migration, or capital;

- it can easily be derived from theoretical models such as random utility maximization models;

- there are multiple methods to account for analytical challenges associated with gravity models such as the use of instrumental variables or fixed effects;

- empirical models can easily be augmented to consider different additional controls and policy variables.

Meanwhile, the researchers claim the limitations of this approach, like:

- the estimation of gravity models requires country pairs detailed data (i.e. data regarding two specific

countries experiencing direct flows between them), which is not always easy to obtain;

- it encounters difficulty when using data sets that include negative or zero values; some solutions are being investigated, but the challenge remains;

- the interpretation of gravity model results from a policy perspective is not always straight forward due to questions regarding data completeness and other influencing factors.

Still, the same cons could be said in the side of the classic regression analyses.

We use the developed form of the model that contains various independent variables in addition to the simple model:

$$
\begin{aligned}
\text { Exp_Index }_{i j t}= & \beta_{0}+\beta_{1} G D P \_ \text {index_Cl } I_{i t}+\beta_{2} G D P \_ \text {index_C2 } 2_{j t}+\beta_{3} G D P \_ \text {ratio } \\
& +\beta_{4} \text { Comborder }_{i j}+\beta_{5} \text { Seaborder }_{i j}+\beta_{6} \text { Dist }_{i j}+\beta_{7} \text { Eurozone }_{i j t} \\
& +\beta_{8} \text { CPI_Ratio } \\
i j t & +\beta_{9} \operatorname{Im}_{-} \text {Euro }_{j t}+\varepsilon_{i j t}
\end{aligned}
$$

where $\beta 0 \ldots \beta 9$ are used as parameters of the model and $\varepsilon_{\mathrm{tij}}$ is an error term. Obviously, not all variables can be meaningful, and therefore the model needs to be calibrated. Thus, we have 22 periods included, 20 cross-sections included and 440 total panel (balanced) observations. 


\section{EMPIRICAL RESULTS AND DISCUSSION}

The modelling resulted that not all variables are significant (Table 2). In particular, the factors of the common border and the presence of the euro in the importing country are insignificant.

Table 2

Model results

\begin{tabular}{|c|c|c|c|c|}
\hline Variable & Coefficient & Std. Error & t-Statistic & Prob. \\
\hline C & 0.481024 & 0.094789 & 5.074671 & 0.0000 \\
\hline GDP_INDEX_C1 & 0.328425 & 0.093131 & 3.526473 & 0.0005 \\
\hline GDP_INDEX_C2 & 0.625664 & 0.091319 & 6.851407 & 0.0000 \\
\hline GDP_RATIO & 0.022931 & 0.006011 & 3.814938 & 0.0002 \\
\hline COMBORDER & -0.010164 & 0.066234 & -0.153462 & 0.8781 \\
\hline SEABORDER & -0.460401 & 0.056958 & -8.083150 & 0.0000 \\
\hline DIST & -0.000128 & $4.82 \mathrm{E}-05$ & -2.663218 & 0.0080 \\
\hline EUROZONE_TRADE & 0.153520 & 0.085608 & 1.793283 & 0.0736 \\
\hline CPI_RATIO & -0.050355 & 0.030029 & -1.676870 & 0.0943 \\
\hline IM_EURO & -0.038273 & 0.062494 & -0.612423 & 0.5406 \\
\hline \multicolumn{7}{|l|}{ Main characteristics of the model } & 53.70494 & \\
\hline R-squared & 0.529203 & F-statistic & 0.000000 & \\
\hline
\end{tabular}

Source: calculated by authors

Conducting the Lagrange test on omitted random effects has shown (Tabl. 3) that two types of random effects should be added to the model: to explain the difference between countries and time periods.

Table 3

Model results: Lagrange Multiplier Tests for Random Effects (Test Hypothesis)

\begin{tabular}{|c|c|c|c|}
\hline & Cross-section & Time & Both \\
\hline & 204.9614 & 2.169779 & 207.1312 \\
\hline Breusch-Pagan & $(0.0000)$ & $(0.1407)$ & $(0.0000)$ \\
\hline & & & 11.16486 \\
\hline Honda & 14.31647 & 1.473017 & $(0.0000)$ \\
\hline King-Wu & $(0.0000)$ & $(0.0704)$ & 11.38848 \\
\hline & & & $(0.0000)$ \\
\hline & 14.31647 & 1.473017 & 8.067627 \\
\hline Standardized Honda & $(0.0000)$ & $(0.0704)$ & $(0.0000)$ \\
\hline & & & 8.350615 \\
\hline Standardized King-Wu & 17.32542 & 1.871119 & $(0.0307)$ \\
\hline Gourieroux, et al.* & $(0.0000)$ & & $(0.0000)$ \\
\hline & & 1.871119 & $(0.0307)$ \\
\hline
\end{tabular}

Source: calculated by authors

The presence of dummy variables in the model made it probable to consider the panel regression exclusively with random effects. If it is theoretically possible to limit fixed effects in time periods, it would be impossible for countries to do this because, for example, Ukraine has the value of EUROZONE_TRADE variable always equal to 0 . Due to such features of the model construction, it would be incorrect to carry out the Hausman test, so it was decided to evaluate the model with random effects as by country, and by time. If intercountry differentiation is understood from the logic of the choice of states, they were specifically selected to have a difference in the degree of development, then 
time differentiation evaluates the overall economic cycle of development of European countries. It should be added that in our research we used quite a small sample of neighbour countries. Such a limitation can lead to some problems. First of all, the residuals in the panel regression can show the autorellation. It can be false one, but the dependence between states also plays an important role. Two variables (Seaborder and Euroze_trade) have very low volatility due to the natural reasons and it may lead to residual autocorrelation as well. Secondly, this model does not include the common factors, which may explain the evolution of macroeconomic parameters, for example, GDP. In fact, there common European policies, directed to stimulating economic growth, therefore, the absence of variables, indicating such policy, may create a further shift in the model. By the way, our model is suggested to solve other hypotheses, therefore we can estimate just the influence of factors, which are present in our previous analysis.

Finally, the next step was to evaluate the model, which excluded minor variables.

As it was explained earlier, due to the method of creating the model and selecting the countries we can observe an autocorrelation in residuals. Moreover, the analysis shows that Residual Cross-Section Dependence exists (Table 5). But it was explained earlier why it cannot be a significant problem for our analysis.

The above values allow us to conduct an economic analysis of the model. In particular, the GDP of the importing country plays a significant role in shaping the country's exports. In particular, the growth of the GDP index in the importing country by 0.01 leads to an increase in the export index to this country by 0.0091 . That means, in fact, that $91 \%$ of additional incomes goes to imports. At the same time, the change in GDP in the exporting country does not play a significant role in the formation of exports: in all models the corresponding coefficient was insignificant.

Table 4

Model results: Panel EGLS (Two-way random effects)

\begin{tabular}{|c|c|c|c|c|}
\hline Variable & Coefficient & Std. Error & $\mathrm{t}$-Statistic & Prob. \\
\hline $\mathrm{C}$ & 0.463000 & 0.118247 & 3.915547 & 0.0001 \\
\hline GDP_INDEX_C2 & 0.911427 & 0.064049 & 14.23012 & 0.0000 \\
\hline GDP_RATIO & 0.024344 & 0.008963 & 2.715892 & 0.0069 \\
\hline SEABORDER & -0.461344 & 0.120131 & -3.840330 & 0.0001 \\
\hline DIST & -0.000164 & $4.23 \mathrm{E}-05$ & -3.875559 & 0.0001 \\
\hline EUROZONE_TRADE & 0.192881 & 0.081609 & 2.363493 & 0.0186 \\
\hline \multicolumn{5}{|c|}{ Effects Specification } \\
\hline & & & S.D. & Rho \\
\hline \multicolumn{3}{|c|}{ Cross-section random } & 0.240179 & 0.2779 \\
\hline \multicolumn{3}{|c|}{ Period random } & 0.073668 & 0.0261 \\
\hline \multicolumn{3}{|c|}{ Idiosyncratic random } & 0.380116 & 0.6960 \\
\hline \multicolumn{5}{|c|}{ Weighted Statistics } \\
\hline R-squared & 0.387512 & \multicolumn{2}{|c|}{ Mean dependent var } & 0.280083 \\
\hline Adjusted R-squared & 0.380114 & \multicolumn{2}{|c|}{ S.D. dependent var } & 0.493185 \\
\hline S.E. of regression & 0.388298 & \multicolumn{2}{|c|}{ Sum squared resid } & 62.42105 \\
\hline F-statistic & 52.38622 & \multicolumn{2}{|c|}{ Durbin-Watson stat } & 0.922664 \\
\hline Prob(F-statistic) & 0.000000 & & & \\
\hline \multicolumn{5}{|c|}{ Unweighted Statistics } \\
\hline R-squared & 0.497805 & \multicolumn{2}{|c|}{ Mean dependent var } & 0.891672 \\
\hline Sum squared resid & 89.81719 & \multicolumn{2}{|c|}{ Durbin-Watson stat } & 0.673426 \\
\hline
\end{tabular}

Source: calculated by authors 
Table 5

Residual Cross-Section Dependence Test

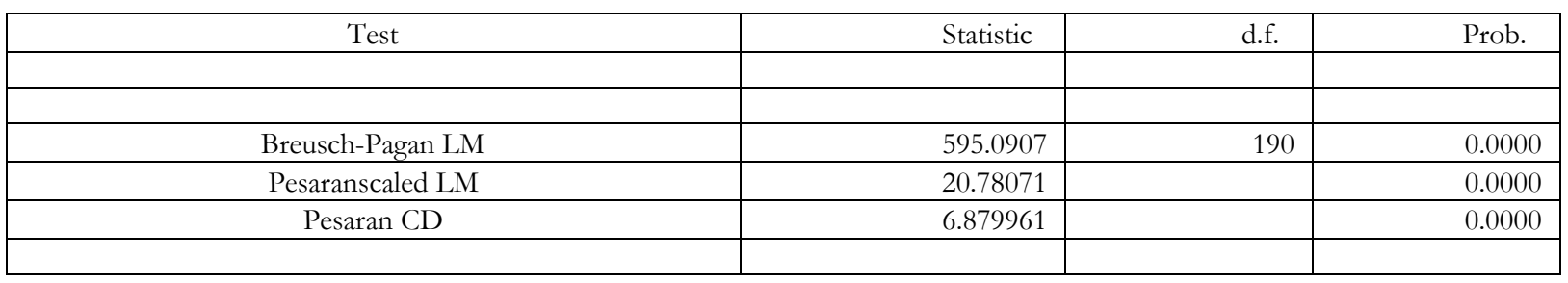

Source: calculated by authors

In turn, the ratio of GDP has a little positive impact. If the economy of the exporter develops faster than the economy of the importer, for example, by $1 \%$, this leads to an increase in exports by about $0.0002 \%$. Perceptibly, this effect will have a real impact only if a country develops much slower than the other one.

The distance between countries is predicted to reduce the volume of exports. In particular, every $1000 \mathrm{~km}$ of road leads to a drop in the export index by 0.016 . Clearly, this value is not critical; it values only about $1.5 \%$ of exports.

Yet, the presence of ports in a common sea significantly affects exports. Surprisingly, the presence of a common land border, in general, is a negligible factor. Noticeably, due to insignificant logistic losses, it was more attractive to carry loads at greater distances. Similarly, the situation with ports shows that neighbouring economies that are close to each other will compete more and more, which means less export to neighbours. The model shows that the Baltic countries reduce the export index by0.46. This coefficient is significant for all modifications of the model, and therefore one can carefully conclude that the countries of one sea basin will understate their exports to each other by at least $40 \%$ in comparison if they were located in different places of Europe. There is a phenomenon of competition.

The existence of a common currency is expected to increase the export index by 0.19 . Namely, the common currency is the basis for the growth of exports by almost one fifth.

Table 6 provides confidence intervals for regression coefficients.

Table 6

Confidence intervals for regression coefficients

\begin{tabular}{|c|c|c|c|}
\hline Variable & \multirow{2}{*}{ Coefficient } & \multicolumn{2}{|c|}{ 95\% CI } \\
\cline { 3 - 3 } & & Low & 0.695439 \\
\hline C & 0.463000 & 0.230562 & 1.037330 \\
\hline GDP_INDEX_C2 & 0.911427 & 0.785525 & 0.041963 \\
\hline GDP_RATIO & 0.024344 & 0.006724 & -0.225201 \\
\hline SEABORDER & -0.461344 & -0.697488 & $-8.08 \mathrm{E}-05$ \\
\hline DUST & -0.000164 & -0.000247 & 0.353300 \\
\hline
\end{tabular}

Source: calculated by authors

As one can see, the impact of the GDP index of the importing country with $95 \%$ reliability can vary between 0.78 and 1.04. The ratio of GDP between the countries impacts on the export index from 0.007 to 0.043 , the presence of a common currency - from 0.03 to 0.35 . The breakdown of the latest indicator can be attributed to significant changes over recent years when two of the five countries joined the euro area. The negative impact of the distance of $1000 \mathrm{~km}$ on the export index is measured from 0.008 to 0.02 , and the presence of joint ports is from 0.22 to 0.70 .

Let us analyse the random effects of countries and periods on the export index (Table 7). As one can see, exports from Estonia to the Baltic countries and Finland have a positive effect of approximately 3.5- 
$5.5 \%$, but Ukraine is underestimated by $2 \%$. Finland's exports to Ukraine are overestimated by $20 \%$, to Lithuania -by 5\%, but lowered to Latvia by 16\%. Latvian exports to Finland, in turn, are overestimated by $8.8 \%$, to Estonia - by $2.2 \%$ and underestimated to Ukraine - by $21.6 \%$ and to Lithuania - by $7 \%$. Lithuania's exports are overestimated to Estonia - by almost 6\% and to Latvia - by 3.4\% but lowered to Ukraine - by $52.9 \%$ and to Estonia - by almost 6\%. Such a huge effect in relations with Ukraine can be explained by the imperfection of Ukrainian legislation, which allowed the import of Lithuanian cars in the last years without customs control. This problem is currently fixed, so one should suppose of a reduction in this effect. Ukrainian exports to Estonia are overestimated by $67.4 \%$, to Latvia - by $21.4 \%$, but to Finland - understated by $29 \%$, to Lithuania - by $3.5 \%$.

Table 7

Random effects for countries

\begin{tabular}{|c|c|}
\hline $\begin{array}{c}\text { Trade } \\
\text { direction }\end{array}$ & Coefficient \\
\hline est_fin & 0.038014 \\
\hline est_lat & 0.034368 \\
\hline est_lit & 0.055635 \\
\hline est_ukr & -0.021034 \\
\hline fin_est & 0.007633 \\
\hline fin_lat & -0.160764 \\
\hline fin_lit & 0.057827 \\
\hline fin_ukr & 0.201478 \\
\hline lat_est & 0.022071 \\
\hline lat_fin & 0.087717 \\
\hline lat_lit & -0.070022 \\
\hline lat_ukr & -0.216544 \\
\hline lit_est & 0.059390 \\
\hline lit_fin & -0.165978 \\
\hline lit_lat & 0.034108 \\
\hline lit_ukr & -0.529077 \\
\hline ukr_est & 0.674592 \\
\hline ukr_fin & -0.289198 \\
\hline ukr_lat & 0.214770 \\
\hline ukr_lit & -0.034987 \\
\hline
\end{tabular}

Source: calculated by authors

Through the analysis of the effects by years demonstrates the cyclicality of the development of trade in the analysed region (Table 8). In Fig. 5 the periods of the rapid development of trade (2002-2008 and 2011-2013) are clearly visible.

Table 8

Random effects by years

\begin{tabular}{|c|c|}
\hline Year & Coefficient \\
\hline 1996 & -0.054161 \\
\hline 1997 & -0.045375 \\
\hline 1998 & -0.035705 \\
\hline 1999 & -0.068869 \\
\hline 2000 & -0.030997 \\
\hline 2001 & -0.010540 \\
\hline 2002 & -0.002415 \\
\hline 2003 & 0.102474 \\
\hline 2004 & 0.096222 \\
\hline 2005 & 0.023378 \\
\hline
\end{tabular}




\begin{tabular}{|c|c|}
\hline 2006 & 0.041945 \\
\hline 2007 & 0.053773 \\
\hline 2008 & 0.045867 \\
\hline 2009 & -0.089330 \\
\hline 2010 & -0.029406 \\
\hline 2011 & 0.034069 \\
\hline 2012 & 0.091523 \\
\hline 2013 & 0.014345 \\
\hline 2014 & -0.006919 \\
\hline 2015 & -0.066210 \\
\hline 2016 & -0.063668 \\
\hline
\end{tabular}

Source: Calculated by authors

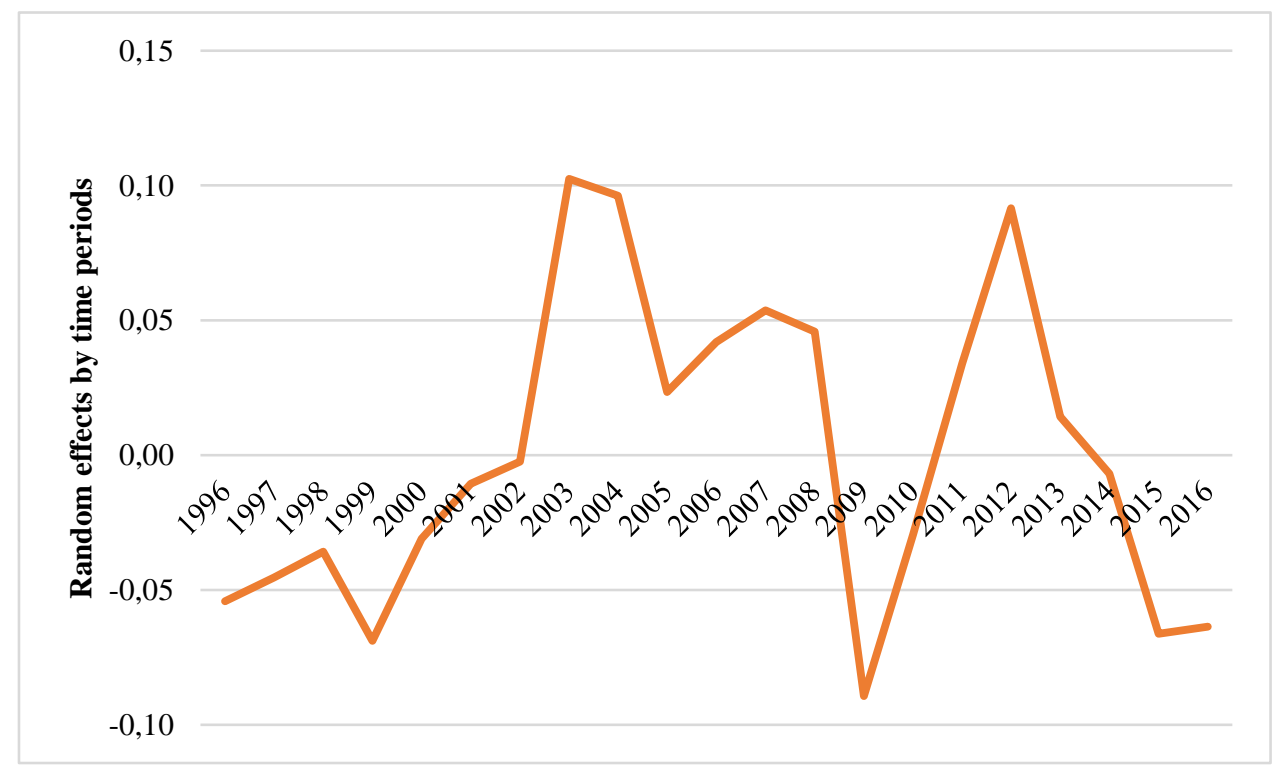

Figure 5. The dynamics of random effects over the years

Source: Calculated by authors

\section{CONCLUSION}

In this section, we summarize results obtained, discuss the limitations of our findings and compare the conclusions with other investigations.

First of all, the conducted study made it possible to check the eight hypotheses (Table 9).

Thus, the analysis allowed formulating the following statements. European countries have already exhausted the potential for developing their own exports. In particular, they remain significant barriers in countries, mainly in Eastern Europe, regarding currency regulation. Elimination of these barriers could allow an increase in the volume of trade between these states by about one-fifth, which is a rather significant indicator.

Distances cease to play a decisive role in the shaping of exports. In particular, the influence of the distance between trading partners leads to a reduction in exports of less than $1 \%$ for most European countries. This shows the insignificant role of transport costs in export operations and the high specificity in the field of logistics.

Countries are trying to increase competitiveness among themselves, as evidenced by the efficiency of exports growth for non-neighbouring countries. Considering the development of transport infrastructure, 
it is possible to significantly increase export volumes in Europe, especially with the involvement of Eastern Europe, which, due to GDP growth would further increase exports.

Economic growth and the equalization in economic conditions offset the differences between countries. Currently, the change in domestic prices does not play a role in exports, the ratio of economies also does not play such an important role as it was in the twentieth century. Therefore, the basis for increasing trade is only the stability of economic development in Europe, transparent rules of the game and the possibility of weakening currency control. Under these conditions, European countries have the opportunity to increase mutually beneficial trade.

Table 9

Results of hypothesis testing

\begin{tabular}{|c|c|}
\hline Hypothesis & Testing results \\
\hline $\begin{array}{l}\text { Hypothesis } 1 \text {. The volume of GDP of the } \\
\text { country positively affects the volume of } \\
\text { exports. }\end{array}$ & Not confirmed. No model found a direct effect on the export index. \\
\hline $\begin{array}{l}\text { Hypothesis } 2 \text {. The volume of GDP of a } \\
\text { partner country positively influences its } \\
\text { import volume. }\end{array}$ & $\begin{array}{l}\text { Confirmed The model showed that the importing country is willing } \\
\text { to spend about } 90 \% \text { of its additional revenues for additional exports. } \\
\text { Thus, countries should be interested in enriching partner countries. }\end{array}$ \\
\hline $\begin{array}{l}\text { Hypothesis 3. The ratio of GDP of trading } \\
\text { partners in the modern world does not play a } \\
\text { significant role in the analysis of exports. }\end{array}$ & $\begin{array}{l}\text { Not supported. Currently, this effect is detected; it allows explaining } \\
\text { from } 0.4 \text { to } 4 \% \text { in the structure of exports. But, it would be wrong to } \\
\text { call this effect significant compared to other factors. However, this } \\
\text { indicator still plays a role. }\end{array}$ \\
\hline $\begin{array}{l}\text { Hypothesis } 4 \text {. The ratio of price levels in } \\
\text { partner countries contributes to the growth } \\
\text { of exports. }\end{array}$ & $\begin{array}{l}\text { Not confirmed. Since the main trade occurs either in US dollars or in } \\
\text { euros that are not devalued so much as other currencies, only the } \\
\text { export price, and not internal prices, is an important factor. } \\
\text { Consequently, the change in domestic prices, both in the importing } \\
\text { country and in the exporting country, does not play a real role in the } \\
\text { formation of exports. }\end{array}$ \\
\hline $\begin{array}{l}\text { Hypothesis } 5 \text {. The presence of common } \\
\text { borders contributes to the growth of } \\
\text { exports. }\end{array}$ & $\begin{array}{l}\text { Not confirmed. The neighbouring countries have a fairly similar } \\
\text { economy and range of goods, which requires the sale of goods } \\
\text { further. Therefore, if common borders had a positive impact on } \\
\text { exports, nowadays, when the level of saturation with standard } \\
\text { products has actually been reached between neighbours, this factor } \\
\text { does not give any advantages. }\end{array}$ \\
\hline $\begin{array}{l}\text { Hypothesis } 6 \text {. A significant distance for the } \\
\text { transportation of goods is an obstacle to the } \\
\text { growth of exports. }\end{array}$ & $\begin{array}{l}\text { Confirmed, although this factor is not very important. It is shown } \\
\text { that each additional } 1,000 \mathrm{~km} \text { distance between countries reduces the } \\
\text { export index by about } 0.1 \% \text {, which is not critical. Even for the } \\
\text { longest distances (up to } 20 \text { thousand } \mathrm{km} \text { ), this only reduces exports } \\
\text { only by } 2 \% \text {. }\end{array}$ \\
\hline $\begin{array}{l}\text { Hypothesis } 7 \text {. The introduction of the euro } \\
\text { has a positive effect on the volume of } \\
\text { exports. }\end{array}$ & $\begin{array}{l}\text { Confirmed. The presence of a common currency allows getting rid } \\
\text { of a bunch of bureaucratic formalities and currency risks, which } \\
\text { gives an opportunity to increase the export by approximately } 20 \% \text {. }\end{array}$ \\
\hline $\begin{array}{l}\text { Hypothesis } 8 . \text { The presence of the euro in } \\
\text { the partner country stimulates exports. }\end{array}$ & $\begin{array}{l}\text { Not confirmed. Only the presence of a stable currency in the partner } \\
\text { country does not prevent currency risks and the corresponding } \\
\text { currency control. Therefore, this factor is not significant. }\end{array}$ \\
\hline
\end{tabular}

Source: formed by authors

Obviously, we need to state some limitations of the analysis. Our research used only five countries, which are located in one European region. The selection of these countries may cause an additional unpredicted shift to our results, therefore, such investigation should be repeated for other sets of countries, and maybe, other sea regions. Especially interesting would provide analysis of Mediterranean Sea countries as they have rather rich possibilities to trade. Another option is to use Atlantic ocean countries as they have absolutely different trade structure with American countries. 
The next limitation is the inclusion in the sample Ukraine. Nowadays, this country is in a war, has an occupied territory, which significantly decreased its production potential, economic growth, amounts of trade etc. Of course, the inclusion of the country, which differs so much from EU states may lead to a definite difference in results. Therefore, the analysis may be repeated for only EU countries. At the same time, we believe that the main findings regarding the influence of the distance between countries, common borders, euro implementation, etc. will remain.

Finally, we should stress the novelty of the results and their difference with other investigations. First of all, we should state that we found no significant influence of common borders between countries, which was one of the main parts of the gravity models earlier. Secondly, the price differentiation in countries has no significant impact on trade volumes. It conflicts with economic theory, so further research is needed in this sphere. Thirdly, we received a hesitancy that common currency always improves trade. In our investigation we have no reasons support the positive effect of euro currency, but the results may change if we take into consideration other set of countries.

\section{ACKNOWLEDGEMENT}

The research is done in the framework of scientific faculty research 16KF040-04 "Steady-state security assessment: a new framework for analysis" (2016-2021) and the project "Innovative and entrepreneurial models of modern universities: World trends, main risks and new opportunities for Ukraine"(2019), Taras Shevchenko National University of Kyiv (Ukraine)

\section{REFERENCES}

Anderson, J. (1978). A Theoretical Foundation for the Gravity Model of Factor Flows (No. 85). Boston College Department of Economics. doi: 10.1126/science.151.3712.867-a

Barro, R. J., \& Sala-i-Martin, X. (1990). Economic growth and convergence across the United States (No. w3419). National Bureau of Economic Research.

Basile, R., Parteka, A., \& Pittiglio, R. (2017). Export diversification and economic development: a dynamic spatial data analysis. Review of International Economics. doi: 10.1111/roie.12316

Ben-David, D., \& Loewy, M. B. (1998). Free trade, growth, and convergence. Journal of Economic Growth. http://doi.org/10.1023/A:1009705702579

Bergstrand, J. H. (1985). The Gravity Equation in International Trade: Some Microeconomic Foundations and Empirical Evidence. The Review of Economics and Statistics. http://doi.org/10.2307/1925976

Binh, D. T. T., Duong, N. V., \& Cuong, H. M. (2011). Applying Gravity model to analyze trade activities of Vietnam. In Forum for Research in Empirical International Trade Working Paper.

Bittmannova, B. (2016). Trade creation and trade diversion in the European Union after creation of Single Market. Journal of Applied Economic Sciences, 11(6), 1176-1184.

Byers, D. A., Işcan, T. B., \& Lesser, B. (2000). New borders and trade flows: A gravity model analysis of the Baltic states. Open Economies Review, 11(1), 73-91. doi: 10.1023/A:1008305213791

Christie, E. (2002). Potential trade in Southeast Europe: A gravity model approach (Vol. 21). Verein" Wiener Institutfür Internationale Wirtschaftsvergleiche".

Cohen, B. J. (2018). Beyond EMU: the problem of sustainability. In The political economy of European monetary unification (pp. 179-204). Routledge.

Costinot, A., \& Rodríguez-Clare, A. (2018). The US gains from trade: Valuation using the demand for foreign factor services. Journal of Economic Perspectives, 32(2), 3-24.

Dudzevičiūtè, G. (2012). Conceptual Approaches Towards Sustainability. Journal of Security \& Sustainability Issues, 1(4). doi: $10.9770 /$ jssi.2012.1.4(3) 
Gelb, A., Melo, M., Denizer, C., \& Tenev, S. (1999). Circumstance and choice: The role of initial conditions and policies in transition economies. The World Bank. doi: 10.1093/wber/15.1.1

Harms, P., \& Méon, P. G. (2018). Good and useless FDI: The growth effects of greenfield investment and mergers and acquisitions. Review of International Economics, 26(1), 37-59.

Eaton, J., \& Kortum, S. (2018). Trade in goods and trade in services. In World Trade Evolution (pp. 82-125). Routledge.

Egger, P. (2002). An econometric view on the estimation of gravity models and the calculation of trade potentials. World Economy, 25(2), 297-312.

Karemera, D., Smith, W. I., Ojah, K., \& Cole, J. A. (1999). A gravity model analysis of the benefits of economic integration in the Pacific Rim. Journal of Economic Integration, 347-367.

Kepaptsoglou, K., Karlaftis, M. G., \& Tsamboulas, D. (2010). The gravity model specification for modeling international trade flows and free trade agreement effects: a 10-year review of empirical studies. The Open Economics Journal, 3(1). doi: 10.1016/S0266-7681(85)80064-4

Kharlamova, G., Stavytskyy, A., \& Zarotiadis, G. (2018). The impact of technological changes on income inequality: the EU states case study. International Studies, 11(2), 76-94.doi: 10.14254/2071-8330.2018/11-2/6.

Korhonen, I. (2001). Progress in economic transition in the Baltic states. Post-Soviet Geography and Economics, 42(6), $440-463$

Krugman, P. (1998). What's new about the new economic geography?. Oxford review of economic policy, 14(2), 7-17.

Lankauskienè, T., \& Tvaronavičienè, M. (2012). Security And Sustainable Development: Approaches and Dimensions In The Globalization Context. Journal of Security \& Sustainability Issues, 1(4). doi: 10.9770/jssi.2012.1.4(5)

Makštutis, A., Balkytè, A., \& Tumalavičius, V. (2012). Security, Sustainability and Competitiveness: Benchmarking Attempts. Journal of Security \& Sustainability Issues, 2(1). doi: 10.9770/jssi/2012.2.1(1)

Oberhofer, H., \& Pfaffermayr, M. (2018) Estimating the Trade and Welfare Effects of Brexit: A Panel Data Structural Gravity Model CESifo Working Paper Series, No. 6828. Available at SSRN: https://ssrn.com/abstract=3129951

Ocampo, J. A. (2018). International asymmetries and the design of the International Financial System 1. In Critical Issues in International Financial Reform (pp. 45-74). Routledge.

Organisation for Economic Co-operation and Developement, O. (2005). Measuring Globalisation: OECD Handbook on Economic Globalisation Indicators. OECD. doi: http://doi.org/10.1787/9789264084360-en

Pietrasieński, P., Ślusarczyk, B. (2015). Internationalization of small and medium enterprises - Empirical research review on barriers to entry into foreign markets. Polish Journal of Management Studies, 11 (1), 113-123.

Ramos, R. (2016). Gravity models: a tool for migration analysis. IZA World of Labor.

Ravishankar, G., \& Stack, M. M. (2014). The Gravity Model and Trade Efficiency: A Stochastic Frontier Analysis of Eastern European Countries' Potential Trade. The World Economy, 37(5), 690-704. doi: 10.1111/twec.12144

Reichert, M. S., \& Jungblut, B. M. E. (2007). European union external trade policy: Multilevel principal-agent relationships. Policy Studies Journal. http://doi.org/10.1111/j.1541-0072.2007.00230.x

Robinson, S., \& Thierfelder, K. (2018). US withdrawal from international trade: Analyzing the impact on the global trading system with a global CGE model and a gravity model. https://www.gtap.agecon.purdue.edu/resources/download/8947.pdf

Rodrik, D. (2018). Whatdotradeagreementsreallydo?. Journal of economicperspectives, 32(2), 73-90.

Sala-I-Martin, X. X. (1996). Regional cohesion: Evidence and theories of regional growth and convergence. European Economic Review. http://doi.org/10.1016/0014-2921(95)00029-1

Santos Silva, J. M. C., \&Tenreyro, S. (2006). The $\log$ of gravity. Review of Economics and Statistics. http://doi.org/10.1162/rest.88.4.641 
State Statistics Service of Ukraine. (2019). Retrieved January 9, 2019, from http://ukrstat.gov.ua/

Stavytskyy, A. (2018a). Geopolitical Climate of Black Sea Region. Emerging Importance of Wider Black Sea Area Security. Lucian Blaga University of Sibiu, 107-117.

Stavytskyy, A., Kharlamova, G., Giedraitis, V., \& Šumskis, V. (2018). Estimating the interrelation between energy security and macroeconomic factors in European countries. Journal of International Studies Vol, 11(3), 217238.doi:10.14254/2071-8330.2018/11-3/18

Stavytskyy, A. (2018b). Influence Of Modern Geopolitical Challenges On State's Economic Security. Bulletin of Taras Shevchenko National University of Kyiv. Economics, 4(199), 45-55. doi: https://doi.org/10.17721/17282667.2018/199-4/6

Ślusarczyk, B., Baryń, M., \& Kot, S. (2016). Tire industry products as an alternative fuel. Polish Journal of Environmental Studies, 25 (3), 1263-1270.

Tešić, J. (2012). Measuring globalization in the context of transition process-the case of Western Balkan countries. Economic Review: Journal of Economics \& Business/EkonomskaRevija: Casopis za EkonomijuiBiznis, 10(1).

Vamvakidis, A. (2008). Convergence in Emerging Europe: Sustainability and Vulnerabilities. IMF Working Paper. http://doi.org/10.5089/9781451870398.001

Westerlund, J., Wilhelmsson, F. (2009). Estimating the Gravity Model without Gravity Using Panel Data. Applied Economics, 41, 1-9. DOI: 10.1080/00036840802599784

World Bank. (2019). GDP (current US\$). Retrieved January 9, 2019, from https:/ / data.worldbank.org/indicator/NY.GDP.MKTP.CD?view=chart

World Bank. (2019). Ukraine Export in thousand US\$ for all countries between 1996 and 2017. Retrieved January 9, 2019, from

https://wits.worldbank.org/CountryProfile/en/Country/UKR/StartYear/1996/EndYear/2017/TradeFlow /Export/Partner/BY-COUNTRY/Indicator/XPRT-TRD-VL\#

Zenonas, N. (2007). Why did Estonia perform best? The north-south gap in the post-socialist economic transition of the Baltic States. Journal of Baltic Studies, 38(1), 21-42. DOI: 10.1080/01629770701223502 


\section{Appendix}

Geographical data about countries

\begin{tabular}{|l|l|r|r|r|}
\hline Country1 & Country2 & Dist & ComBorder & SeaBorder \\
\hline ukr & est & 1368 & 0 & 0 \\
\hline ukr & fin & 1452 & 0 & 0 \\
\hline ukr & lat & 1048 & 0 & 0 \\
\hline ukr & lit & 763 & 0 & 0 \\
\hline lat & est & 312 & 1 & 1 \\
\hline lat & fin & 399 & 0 & 1 \\
\hline lat & lit & 289 & 1 & 1 \\
\hline lat & ukr & 1048 & 0 & 0 \\
\hline lit & est & 599 & 0 & 1 \\
\hline lit & fin & 686 & 0 & 1 \\
\hline lit & lat & 289 & 1 & 1 \\
\hline lit & ukr & 754 & 0 & 0 \\
\hline est & fin & 87 & 0 & 1 \\
\hline est & lat & 308 & 1 & 1 \\
\hline est & lit & 596 & 0 & 1 \\
\hline est & ukr & 1355 & 0 & 0 \\
\hline fin & est & 90 & 0 & 1 \\
\hline fin & lat & 398 & 0 & 1 \\
\hline fin & lit & 685 & 0 & 1 \\
\hline fin & ukr & 1444 & 0 & 0 \\
\hline
\end{tabular}

Source: Authors compilation on the base of maps.google.com 